\title{
Patterns and Drivers of Mobile Telephony for Sustainable Livelihood among Farming Households in Kwara State, Nigeria
}

\author{
Jubril Olayinka Animashaun ${ }^{1}$, Segun Bamidele Fakayode ${ }^{2}$, Kazeem Adebayo Idris ${ }^{3}$, Khairat F \\ Adedokun ${ }^{4}$
}

\section{N F O}

Received 19 March 2014

Accepted 27 Aug 2014

Available on-line 6 Oct 2014

Responsible Editor: K. Rajkai

Keywords:

mobile phones, agricultural

information, sustainable

capitals.

\begin{abstract}
$\underline{\text { A B S T R A C T }}$
Recently, it is acknowledged that mobile phones provide multiple functionalities and diverse applications that affect all forms of capital accumulation, necessary for sustainable livelihood. However, there is no empirical result regarding the impact of mobile phones on asset accumulation in Nigeria. This study examined the socio-economic determinants of mobile phone use and intensity of use for sustainable capital formation in farming households in Kwara state, Nigeria. Accordingly, 120 rural farming households were randomly sampled and count data on the number of calls made with respect to livelihood capitals generated. Binary logistic regression and zero-inflated negative binomial regression models were used in analyzing the data. The study revealed that $73 \%$ of the respondents have access to mobile phone use. The study identifies major uses of mobile phone for sustainable livelihood enhancement activities. Significant determinants of mobile phone use are; possession of formal education, household size, age, marital status, annual farm income, diversity of crop cultivated and the number of family members living outside the community $(\mathrm{p}<0.05)$. This study highlights the relevance of mobile phones for sustainable development and recommends the need for increased investment in facilitating access to mobile phone use across rural communities in Nigeria.
\end{abstract}

\section{Introduction}

Knowledge flow (information) and innovation are widely regarded as key drivers and contributors to economic growth and it is clear from literatures that information and communication technologies (ICTs) are deeply implicated in knowledge flow and innovation systems (Verlaeten, 2002), and in sustainable development (Scoones, 2009). Specifically, agricultural information, in addition to the coordination of transportation and the enhancement of development activities (Saunders, Warford, and Wellenius, 1994), offers prospect for improving small-scale agricultural production by linking increased production to remunerative markets, thus leading to improved rural livelihoods, food security and national economies. Moreover, if getting the right information to farmers, when and where needed, in a language and tone they understand and can easily access can be recognized as vital to the success of the agricultural sector as the right type of soil, adequate water, sunlight and any other input, then, information flow should be seen as critical to the sustainability of the existing livelihood systems of rural farming households.

Meanwhile, a significant development trend witnessed in recent years is the exponential growth of mobile phones subscription in many developing countries. Wade (2004) showed that almost one in five Africans owns a phone and estimates put the number of mobile phones subscribers in Nigeria as 95 million accounting for $63 \%$ of the estimated 150 million human population in the country (NBS,

\footnotetext{
${ }^{1}$ Jubril Olayinka Animashaun

Department of Agricultural Economics and Farm Management, P.M.B. 1515, University of Ilorin, Nigeria reals4u@yahoo.com, +234-803-8550618

2 Segun Bamidele Fakayode

Department of Agricultural Economics and Farm Management, P.M.B. 1515, University of Ilorin, Nigeria

${ }^{3}$ Kazeem Adebayo Idris

Department of Agricultural Extension and Rural Sociology, University of Ibadan, Nigeria

${ }^{4}$ Khairat F Adedokun

Department of Agricultural Extension and Rural Sociology, University of Ilorin, Nigeria
} 
2011). Mobile telephony technologies have enabled the poorest countries to extend telecommunication network coverage to the mass of their populations including the rural poor. Pointedly, studies conducted in South Asia (De Silva, 2008) and sub-Saharan Africa (Donner, 2009 and Gakuru et al., 2009) identify mobile phones as a key innovative technology in support of rural livelihoods. In the same direction, studies equally recognize the roles of mobile phones access to include areas that are not exclusively agriculture, but also include new forms of micro-financial service provision and microenterprise support, data gathering and dissemination for projects concerned with social development covering education, health, the environment and humanitarian relief in response to disasters and emergencies (Duncombe, 2012). Mobile phones are also reportedly used for advocacy and campaigning on livelihood-centered development issues (Hellstrom, 2010; Kinclade and Verclas, 2008)

However, impact of mobile phone on sustainable livelihood will be incomplete if there is no understanding of how information exchange, brought about by the use of mobile phones, leads to a reduction in rural households' vulnerabilities (Duncombe, 2012). First, livelihoods analysis needs to take into account the changing socio-economic and demographic such as enhanced urban-rural links, rising labour migration and the increasing dispersal of the household unit which have impacted on the traditional views of livelihood vulnerability and created new demands for better information flows and communication services, hence emphasizing the potential benefits of mobile phones to fulfill these needs. Second, the traditional livelihood assets were developed within the context of traditional agriculture (Carney et al., 1999), and it underplays recent understandings of the importance of certain livelihood assets like social networks, agency, knowledge, cognition and capabilities in livelihood enhancement (Scoones, 2009) and which are equally identified to be strengthen through the use of mobile telephony.

In order to correct the imbalances in the way capitals are specified within the sustainable livelihood framework and to further emphasizes the role of information in sustainable development, a three-fold approach to re-defining assets was proposed by Duncombe (2012) that encompasses a broader and more relevant spectrum and incorporates the role of information. First, Duncombe (2012) proposes that assets could be reconceived according to resource-based assets (RBA) which include the existing categories of physical, financial and natural capital represented in the original livelihoods pentagon (DfID, 1999); network-based assets (NBA) that are derived from connections (social, political, cultural capital); and cognitive-based assets (CBA) comprising human and psychological capital including competencies (knowledge, skills, attitudes) (Duncombe, 2012). Second, it recognizes the role of information as an essentiality to individuals' awareness of, and ability to utilise, all assets; and the use of information in making decisions pertaining to livelihood strategies.

Building on these vital and emerging concepts of sustainable livelihoods, this study explores the role of mobile telephony in sustainable livelihood among rural farmers in Kwara State, Nigeria.

Specifically this study;

- identifies the livelihood activities that mobile phones are used for,

- examines the socio-economic determinants of the use of mobile phones, and,

- evaluates the socio-economic determinants of intensity of mobile phone use

This study is justified on two grounds. First, it guides policy makers on investment decisions particularly at the nexus between investments in roads, markets and communication technologies. Second, it adds to the understanding of sustainable livelihoods particularly as it relates to the roles of information and mobile telephony and the changing contexts of sustainable livelihoods.

A review of past inquiries into the perceived attributes and drivers of mobile phones use within livelihood framework suggest that mobile telephony can be an asset for development by enabling the rural poor to respond more efficiently to external economic opportunities or threats (Abu and Scott, 2001). Onwuemele (2011) concluded that that level of education, income, social network and membership of groups are the major determinants of mobile phones ownership and usage among rural farmers in Ovia North East Local Government Area of Edo State, Nigeria. McNamara (2003) observes that mobiles phones can empower the rural poor to lobby for and demand a higher priority for themselves through an increase in access to information which can assist in sound decision-making. 
Donner (2008), however, cautions that although mobile telephony can serve as a development tool, the extent to which it does so is dependent on the process of economic development in general. The availability, quality, and cost of communication are important factors to consider in the enhancement of commerce and trade (Martin, 2010) and according to McNamara (2003), rural residents, who comprise a substantial majority of the world's poorest, expend substantial amounts of valuable resources such as time and money to facilitate communication with family, trading partners, health providers, and other suppliers of economic necessities.

It is obvious from literatures reviewed that empirical studies that focus on the impact of mobiles phones on rural livelihoods in Nigeria are sparse. Apart from Onwuemele (2011), no other study from the literatures reviewed in this study established the connection between the use of mobile telephony and livelihood activities in Nigeria. This study therefore builds on Onwuemele (2011) and in addition to Onwuemele (2011), assessed the socio-economic determinants of intensity of mobile phone usage among farming households in Kwara State, Nigeria.

\section{Methodology}

This study was conducted in Kwara State, Nigeria. The state is located between Latitudes 110 2' and $11045^{\prime} \mathrm{N}$ and between Longitude $2045^{\prime}$ and $604^{\prime} \mathrm{E}$. Agriculture is the main source of the economy. About $58.5 \%$ of rural populace in Nigeria owned or have access to mobile telephones in Nigeria (NBS, 2011) and Kwara State ranks the 11th position with respect to distribution of access to mobile telephony in Nigeria (NBS, 2011).

Respondents for this study comprised of rural, small-scale farming households and they were sampled using a three-stage sampling procedure. The first stage involved the purposive selection of two agricultural zones out of the four Agricultural zones in the Study area as defined by the Kwara State agricultural development project (KwADP). Agricultural zones C and B were nonprobabilistically sampled. The second stage involved a random sampling of four communities in each of the selected Agricultural zones and the third stage involved the random sampling of fifteen farming households in each community in the study area in which the household head was chosen as the representative of the household. The study only chooses these two agricultural zones because of the financial and time limitations that would be imposed on the study as a result of sampling from the whole of the study area. All together, a total of 120 households/respondents were sampled in the study area.

A structured questionnaire was designed to collect primary data. The study equally utilised secondary data documented at various levels of Statistical Agencies.

\section{Econometric Analysis}

This study uses a Logit regression model to identify the factors that affect the probability of a respondent household to own and use the mobile phone and due to the count nature of the dependent variable, the Zero Inflated Negative Binomial Regression model for factors that affect the intensity of mobile phone use.

In modeling the likelihood of owning and using mobile phone, the dependent variable $(\mathrm{Y})$ is limited to only two possibilities ( $\mathrm{Y}=1$ for households own and use the mobile phones and $\mathrm{Y}=0$ otherwise). In this case, a Logit model can be used to examine the impacts of a set of independent variables $(\mathrm{X} 1, \mathrm{X} 2, \ldots, \mathrm{Xn})$ on the logistic function of the probability $(\mathrm{P})$ for $\mathrm{Y}=1$. Estimation results of a Logit model can be used to identify factors that significantly contribute to the probability for $Y=1$. A Logit model used is represented by the following function:

$$
\text { (1) } P=\frac{e^{x^{\prime} \beta}}{1+e^{x^{\prime} \beta}}
$$

Central to the use of Logit regression is the transformation of $\mathrm{p}$ given by $\mathrm{Y}$

$$
\begin{aligned}
& \text { (2) } Y=\ln (p / 1-p) \\
& \text { (3) } Y=\alpha \sum_{1}^{n} \beta i X i+e
\end{aligned}
$$


With Y being the latent variable representing 1 if the households own and use the mobile phones for identified sustainable livelihood assets accumulation and 0 otherwise and Xi being the variables of interest that could influence use of mobile phone for livelihood capital accumulation and include; age, farm size, household size, dummy for presence of family members living outside the community, literacy level of respondents, gender of the respondent, marital status of respondents, farm size, diversity of crops grown, annual household farm income, access to mobile phone services, access to electricity power supply and $\mathrm{e}$ is the error term. $\alpha$ is the constant and $\beta$ are the coefficients to be estimated.

In addition to the Logit model, the Zero Inflated Negative Binomial Regression model was used to identify the factors that determine the intensity of using the mobile phone for sustainable livelihood assets accumulation. The zero-inflated negative binomial regression is for modeling count variables with excessive zeros and it is usually for over dispersed count outcome variables (Cameron and Trivedi, 1990; and Winkelmann 2000). A zero-inflated model assumes that zero outcomes arise due to two different processes. For instance, in this study, the two processes are that a respondent has access to mobile phone uses or doesn't have access. If no access, the only outcome possible is zero and if there is access, then, it is a count process. The two parts of the a zero-inflated model are a binary model, usually a Logit model to model which of the two processes the zero outcome is associated with and a count model, in this case, a negative binomial model, to model the count process

The dependent variable in this case is a count data and it represents the average number of phone calls made per week by respondents/household using his/her mobile phone with respect to the identified livelihoods capitals. The study utilized the calls made and not received because the responsibility is on the respondent who wants to accumulate capital to demand or request for such from source(s) identified.

The general canonical regression specification for a variable $\mathrm{Y}$ that is a count of events is the Poisson regression:

$$
\text { (4) } F(y i / x i)=\frac{e^{-\lambda(x)} \lambda i(x)(y)}{\Gamma(1+y i)}
$$

Following Wooldridge (2002) the expected number of the events, yi per period is given as:

$$
\text { (5) } E(y i / x i)=\operatorname{var}[y i / x i]=\lambda=\exp \left(\alpha+X^{\prime} \beta\right)
$$

for $\mathrm{i}=1,2, \ldots, \mathrm{m}$

where $\lambda \mathrm{i}=\exp \left(\alpha+X^{\prime} \beta\right)$,

$\mathrm{yi}=0,1, \ldots, \mathrm{i}$ is the number/count of calls made by respondent/household with respect to identified sustainable capitals,

and $\mathrm{X}=\mathrm{a}$ vector of predictor variables which include; gender, household size, marital status of respondent, farm size in ha, average household annual farm income, Age of the respondent, dummy for position in such social organization, dummy for literacy ability of respondent, number of family members living outside the community, $\alpha$ is the constant and $\beta$ are the coefficients to be estimated and $\mathrm{e}$ is the error term.

\section{Results and Discussion}

\subsection{Socio-Economic Distribution of Respondents}

The distribution of the respondents' socio-economic characteristics is presented in Table 1. 
Table 1. Socio-Economic Distribution of Respondents

\begin{tabular}{|c|c|c|c|}
\hline VARIABLES & & Frequency & Percent \\
\hline \multirow[t]{2}{*}{ Gender } & MALE & 95 & 79.2 \\
\hline & FEMALE & 25 & 20.8 \\
\hline \multirow{3}{*}{ Marital status } & SINGLE & 6 & 5.0 \\
\hline & MARRIED & 109 & 90.8 \\
\hline & WIDOWED & 5 & 4.2 \\
\hline \multirow{6}{*}{ Educational Status } & NO FORMAL & 34 & 28.3 \\
\hline & ARABIC & 5 & 4.2 \\
\hline & ADULT & 6 & 5.0 \\
\hline & PRY & 22 & 18.3 \\
\hline & SEC & 34 & 28.3 \\
\hline & TERTIARY & 19 & 15.8 \\
\hline \multirow[t]{6}{*}{ Age } & $<35$ & 18 & 15.0 \\
\hline & $36-45$ & 53 & 34.2 \\
\hline & $46-55$ & 29 & 24.2 \\
\hline & $56-65$ & 14 & 21.6 \\
\hline & $>65$ & 6 & 5.0 \\
\hline & $\begin{array}{l}<2 \\
2-4\end{array}$ & $\begin{array}{l}9 \\
9\end{array}$ & $\begin{array}{l}7.5 \\
7.5\end{array}$ \\
\hline \multirow[t]{2}{*}{ Household Size } & $5-7$ & 53 & 34.2 \\
\hline & $8-10$ & 28 & 22.5 \\
\hline \multirow[t]{4}{*}{ Farm size (ha) } & $\begin{array}{l}<1 \\
2-4\end{array}$ & $\begin{array}{l}20 \\
29\end{array}$ & $\begin{array}{l}16.7 \\
24.2\end{array}$ \\
\hline & $4.1-6$ & 29 & 24.2 \\
\hline & $6.1-8$ & 22 & 18.3 \\
\hline & $<100000$ & 5 & 4.2 \\
\hline \multirow{7}{*}{ Annual Household Farm Income } & $110000-200000$ & 11 & 9.2 \\
\hline & $151000-250000$ & 6 & 5.0 \\
\hline & $251000-350000$ & 14 & 11.7 \\
\hline & $351000-450000$ & 31 & 25.8 \\
\hline & $451000-550000$ & 37 & 30.8 \\
\hline & $>550000$ & 16 & 13,3 \\
\hline & NO & 32 & 26.7 \\
\hline \multirow[t]{2}{*}{ Own a Mobile Phone } & YES & 88 & 73 \\
\hline & YES & 94 & 78.3 \\
\hline \multirow[t]{2}{*}{ Access To Mobile Service } & NO & 26 & 21.7 \\
\hline & YES & 105 & 87.5 \\
\hline Access To Power Supply & NO & 15 & 12.5 \\
\hline
\end{tabular}

Source: Field survey, 2012 
As revealed in the Table, our respondents comprised majorly of male $(79 \%)$, are married $(90 \%)$ and possess one form of formal education (70\%) in the form of Arabic, primary, secondary and tertiary type of education (Table 1). Our respondents are more likely in the active age category with more than $50 \%$ of them within the age bracket of 36 and 55years of age. The household distribution of our respondents reflects the marital statuses and $34 \%$ of them posses between 5 to 7 household size. About $48 \%$ of the respondents cultivate farm with the sizes ranging between 2 and 6 ha. The mean annual average household farm income is $\mathrm{N} 400,000$ of which about $50 \%$ of the respondents realized this from farm activities.

The relatively high marital status of the respondents indicates the significance of having a family to farm work. This is because; marriage could lead to having a large household size which would be necessary to improve agricultural productivity and farm income. Furthermore, a relatively large household size would most likely indicate the presence of one or more household members living outside the community and thereby necessitating the need for maintaining social communicate through a medium, preferably a mobile phone. The cultivation of large acreage of farm land as observed from the Table may signify the need for adequate agricultural market information, information on agricultural input supply and general information as it pertains to improving sales and productivity which can predisposes our respondents in this study to make use of the potentials of mobile telephony to enhance such possibilities.

As revealed in the Table, $73 \%$ of the respondents own and use mobile phones while $26 \%$ reported not having access to mobile phone services and $15 \%$ reported not having access to electricity supply (Table 1). As expected the demand for mobile phones is hinged on the provision of mobile telephone services and the provision of electricity to power the phone batteries. The availability of these two, mobile phone service and electricity are directly responsible for the use of mobile phone phones in the study area.

\subsection{Identified uses of Mobile phones for Sustainable Livelihood Activities}

The current study adopts the sustainable assets as described by Duncombe (2012) to include physical, financial and natural capital represented in the original livelihoods pentagon (DfID, 1999); network-based assets (NBA) that are derived from connections (social, political, cultural capital); and cognitive-based assets (CBA) comprising human and psychological capital including competencies (knowledge, skills, attitudes) to arrive at livelihood-based uses of mobile phones. An overall list of uses identified in this study is as described and ranked in Table 2.

Table 2. Ranks of Identified Uses of Mobile Phones for Livelihood Activities

\begin{tabular}{lllllr}
\hline \multirow{2}{*}{ RANK } & IDENTIFIED MOBILE PHONES USE FOR LIVELIHOOD & \multicolumn{2}{c}{ YES } & \multicolumn{3}{c}{ NO } \\
\hline $\mathbf{1 .}$ & ACTIVITIES & FREQ & $\%$ & FREQ & $\%$ \\
$\mathbf{2}$ & RETTING IN CONTACT WITH FAMILY MEMBER & 88 & 100 & \\
\hline $\mathbf{3}$ & $\begin{array}{l}\text { SOURCE FOR TRANSPORT FACILITIES FOR } \\
\text { AGRICULTURAL COMMODITIES }\end{array}$ & 70 & 90.9 & 8 & 9.1 \\
\hline $\mathbf{4}$ & GETTING IN TOUCH WITH SOCIAL GROUP MEMBERS & 76 & 86.4 & 12 & 13.6 \\
\hline $\mathbf{5}$ & SOURCE FOR BUYER OF AGRICULTURAL PRODUCE & 74 & 84.1 & 14 & 13.9 \\
\hline $\mathbf{6}$ & FOR RECEIPT OF CREDIT (AIRTIME) TRANSFER & 66 & 75 & 22 & 25 \\
\hline
\end{tabular}




\begin{tabular}{|c|c|c|c|c|c|}
\hline 9 & $\begin{array}{l}\text { FACILITAING ACCESS WITH AGRICULTURAL } \\
\text { EXTENSION OFFICERS }\end{array}$ & 56 & 63.6 & 32 & 36.4 \\
\hline 10 & SOURCING FOR AGRICULTURAL CREDIT & 50 & 56.8 & 38 & 43.2 \\
\hline 11 & FLASHLIGHT APPLICATION FOR LATE NIGHT WORK & 48 & 54.5 & 40 & 45.5 \\
\hline 12 & $\begin{array}{l}\text { FOR RELIGIOUS GUIDANCE WITHIN THE } \\
\text { COMMUNITY }\end{array}$ & 40 & 45.5 & 48 & 54.5 \\
\hline 13 & $\begin{array}{l}\text { USE AS A SOURCE OF INCOME GENERATION } \\
\text { (PHONE BOOTH) }\end{array}$ & 34 & 38.6 & 54 & 61.4 \\
\hline 14 & $\begin{array}{l}\text { USE GPRS APPLICATION FOR WEATHER AND } \\
\text { CLIMATIC INFORMATION }\end{array}$ & 3 & 3.4 & 85 & 96.6 \\
\hline
\end{tabular}

Source: field survey, 2012

All of the respondents, $(100 \%)$, used mobile phones for contacting a family member within the period under focus (Table 2). This could be as a result of enhanced geo-spatial distribution and migration of the rural households to a different location and the need to communicate among family members. The second most frequently cited use of the mobile phone, indicated by $70 \%$ of respondents, was for recruiting farm labour $(90 \%)$ (Table 2). Farm labour plays a critical role in agricultural productivity and access to timely supply of labour is the desire of most farmers. Initially, farmers would have to travel long distances to recruit or wait endlessly for the availability of farm workers for land preparation and weeding. This is more profound with the lack of agricultural machines like farm tractors and plough which would reduce the demand for farm labour and the increasing rural-urban migration witnessed in most rural communities.

The use of the mobile phone sourcing transport facilities and contacting social group member were the third in rank (86\%) of the use of mobile phone in the study area (Table 2). Getting in touch with a social group member can facilitate networking which would ultimately influence livelihoods.

The use of the mobile phone for sourcing agriculture output buyer was reported as the $4^{\text {th }}$ use identified by respondents in the study area and the transfer of airtime which is a form of credit (e-cash) transfer was mentioned by nearly $75 \%$ of the respondents. Approximately of the $71 \%$ and $69 \%$ of the respondents indicated the use of mobile phones for time management and sourcing for agricultural information (Table 2). Most mobile phones contain the clock application which is useful coordination of farm activities and the monitoring of daily schedules. Specifically, respondents indicated using the mobile phone to clarify agricultural methods learned during training sessions and the sourcing of agricultural information from friends, social group members and extension agents.

The findings reveal that the more than $50 \%$ of the respondents reported the use of mobile phones for 11 out of the 14 identified uses of mobile phones in the study area (Table 2).

\subsection{Socio-Economic Factors that Influence the Usage of Mobile Phones}

The result of the socio economic determinants of use of mobile phones in the study area is presented in Table 3. 
Table 3. Socio Economic Determinants of Mobile Phone Use

\begin{tabular}{|c|c|c|c|}
\hline INDEPENDENT VARIABLES & COEFFICIENT & STD ERROR & P-VALUE \\
\hline GENDER (MALE) & 0.1767 & 0.5217 & 0.7 \\
\hline AGE & -0.139 & 0.0347 & $0.001^{* * *}$ \\
\hline MARITAL STATUS & 0.124 & 0.684 & 0.856 \\
\hline EDUCATION (ANY FORMAL) & 1.088 & 0.188 & $0.001^{* * *}$ \\
\hline FARM SIZE & 0.004 & 0.1007 & 0.96 \\
\hline DIVERSITY OF CROPS GROWN & 0.394 & 0.2629 & 0.134 \\
\hline HOUSEHOLD SIZE & 0.2339 & 0.1036 & $0.024^{* * *}$ \\
\hline ANNUAL FARM INCOME & $2.47 e-06$ & $8.61 \mathrm{e}-07$ & $0.004^{* * *}$ \\
\hline CONSTANT & 5.9 & 3.66 & $0.10^{*}$ \\
\hline 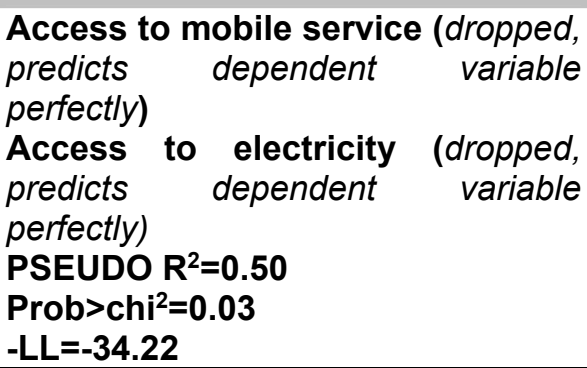 & & & \\
\hline
\end{tabular}

Source: Field survey, 2012

As revealed in Table 3, the model is a good fit and significantly explains the variables that are responsible for the variation in the use and non-use of mobile phones in the study area (Pseudo $\mathrm{R}^{2}=50$; $\mathrm{P}<.005)$ As expected, availability of mobile phone service and electricity predict the use of mobile phones in the study area perfectly and as such, were dropped from the analysis (Table 3).

Furthermore the Table reveals that age, household size, possession of formal education and household farm income were the significant variables that explain the variation in use and non-use of mobile phones by respondents in the study area (Table 3 ). Specifically, the study indicates that as age of respondents increases, the chances of using or owning a mobile phone equally reduces $(p=0.01)$. This may be due to the fact that mobile phones like any ICT, is a product of this millennium which may not be familiar to members of the relatively older members of the society, more importantly if such members are not used to it before. In this case, respondents within the higher ages categories when compared to those within the lower ages may not be know how to operate the functions and workings of the applications on mobile phones. The possession of formal education equally increases the chances of the use of mobile phones by respondents $(p=0.01)$. The possession of formal education enhances the ability to read and write, which would facilitate the ability to operate the mobile phone. The presence of a large household size would within the context of livelihood activities encourages enhanced communication of members and as such facilitate the use of mobile phones as observed in this study ( $\mathrm{p}=0.02$ ). Finally, as revealed in the study, respondents with a relatively higher annual farm income are more likely to make use of mobile phones than others who are not $(\mathrm{p}=0.01)$. This study findings is in line with Onwuemele (2011) which indicated the level of education, income, social network and membership of groups are the major determinants of mobile phones ownership and usage among rural farmers in Ovia North East Local Government Area of Edo State, Nigeria and Rogers (2003) individuals which ascribed socio-economic status to technology adoption.

\subsection{Socio Economic Determinants of the Intensity of Mobile phone Usage}

The result of the socio-economic determinants of intensity of mobile phone use is presented in Table 4 . 
Table 4. Socio Economic Determinants of Intensity of Mobile Phone Usage

\begin{tabular}{|c|c|c|c|}
\hline INDEPENDENT VARIABLES & COEFS & STD ERROR & P-VALUE \\
\hline CONSTANT & 1.079 & 0.506 & $0.073^{*}$ \\
\hline $\begin{array}{l}\text { POSITION IN SOCIAL GROUP (ORDINARY } \\
\text { MEMBER) }\end{array}$ & -0.062 & 0.1054 & 0.5 \\
\hline EDUCATION (ANY FORMAL) & 0.003 & 0.083 & 0.969 \\
\hline AGE & -0.02 & 0.0108 & $0.013^{* * *}$ \\
\hline MARITAL STATUS (married) & 0.4652 & 0.1584 & $0.003^{* * *}$ \\
\hline ANNUAL FARM INCOME & $1.33 e-06$ & $5.96 e-07$ & $0.02^{* *}$ \\
\hline FARM SIZE & -0.083 & 0.0506 & 0.101 \\
\hline DIVERSITY OF CROPS CULTIVATED & 0.199 & 0.090 & $0.028^{* *}$ \\
\hline HOUSEHOLD SIZE & 0.038 & 0.062 & 0.53 \\
\hline $\begin{array}{l}\text { NUMBER OF FAMILY MEMBER LIVING } \\
\text { OUTSIDE THE COMMUNITY }\end{array}$ & 0.215 & 0.051 & $0.01^{* * *}$ \\
\hline $\begin{array}{l}\text { INFLATE } \\
\text { CONSTANT }\end{array}$ & -1.01 & 0.206 & $0.00^{\star * *}$ \\
\hline Inalpha & -30.8 & 249.5 & 0.9 \\
\hline $\begin{array}{l}\text { Alpha } \\
\text {-LL=-266 } \\
\text { ZERO OBS }=32 \\
\text { NON-ZERO OBS=88 } \\
\text { PR>CHI2=0.001 } \\
\text { LR(Chi2) }=127\end{array}$ & $4.12 \mathrm{e}-14$ & $1.03 e-11$ & \\
\hline
\end{tabular}

The zero-inflated negative binomial regression model as a whole is significantly different from an empty model without any predictor variables in it $(\mathrm{P}>\mathrm{Chi} 2=0.01)$. As revealed in the Table; age $(\mathrm{p}=0.01)$, marital status $(0.01)$, household farm income $(\mathrm{p}=0.02)$, diversity of crop cultivated $(\mathrm{p}=0.02)$, number of family members living outside the community $(\mathrm{p}=0.01)$, were all significant socioeconomic variables responsible for the variation in the number of phones made by respondents for identified livelihood assets accumulation in the study area (Table 4).

Specifically, the negative-significance of the older age category to number of calls made can imply that respondents in the older age category may not make phone calls (but can receive) for accessing identified livelihoods of interest in the study area. Married respondents may have a greater need for more intense use of phone because of their engagements in relatively more livelihood activities. Equally, respondents with a higher farm income may require a greater need for phone use and respondents who have cultivate more diverse crop may have a higher need for phone use to contact buyers, source for agricultural information and suppliers of agric inputs to improve on their productivity. Expectedly, respondents with a larger members living outside the community may make more use of the mobile phones to contact and facilitate strengthening of familial ties.

\section{Conclusion and Recommendations}

This study examined the use and intensity of mobile phones for sustainable livelihoods of rural farming households in Kwara State, Nigeria. It investigated also the socio-economic determinants of mobile phone use for sustainable livelihood. 
The study was conducted with a view to offered guides on investment decisions in rural infrastructures and communication technologies in the rural areas as it implicates policy formulation and expanding the scope of knowledge on sustainable livelihood analysis

The study identifies key livelihood asset of interest that mobile phones are used for by respondents. Important socio-economic determinants of mobile phone use and intensity of use by respondents include age, household size, possession of formal education, household farm income, marital status, diversity of crop cultivated and the number of family members living outside the community.

Based on these findings, this study recommends relevant stakeholders increase investment in strategies in facilitating rural communities' access to communication (mobile phones) facilities as this is expected to reduce their vulnerability to external shocks and improve on their livelihood activities.

\section{References}

Abu M., and Scott A. 2001. Understanding livelihoods that involve micro-enterprise: Markets and technological capabilities in the SL framework. Intermediate Technology Group. Retrieved on February 09, 2009, from http://www.itdg.org.

Cameron, A. C. and Trivedi, P.K. 1990. Regression-based tests for overdispersion in the Poisson model. Journal of Econometrics, 46(3): 347-364.

Carney, D., Drinkwater, M., Rusinow, T., Neefjes, K., Wanmali, S. and Singh, N. 1999. Livelihood Approaches Compared, Department for International Development, London.

De Silva, H. 2008. Scoping Study: ICT and Rural Livelihoods - South Asia Component (Draft), International Development Research Centre, New Delhi. http://www.enrap.org/research/icts-for livelihoodsresearch/Scoping\%20Study\%20\%20ICT\%20and\%20Rural\%20Livelihoods/Final\%20report\%20of\%2 0scoping\%20study\%20for\%20ICTRL\%20in\%20South\%20Asia\%20focus\%20countries

DFID, 1999. Sustainable Livelihood Guidance Sheet Section 2, DFID, London http://www.livelihoods.org/info/guidance_sheets_pdfs/section2.pdf

Donner, J. 2009. Mobile-based livelihood services in Africa: pilots and early deployments. In M. FernandezArdevol and Ros, A. (Eds) Communication Technologies in Latin America and Africa: A Multidisciplinary Perspective: 37-58, Barcelona, IN3.

Donner, J. 2008. Research approaches to mobile use in the developing world: A review of the literature. The Information Society, 24(3), 140-159.

Duncombe, R.A. 2012. Understanding Mobile Phone Impact on Livelihoods in Developing Countries:A New Research Framework. July. www.http://www.sed.manchester.ac.uk/idpm/research/publications/wp/di/index.htm

Duncombe, R.A. 2006. Using the livelihoods framework to analyse ICT applications for poverty reduction through microenterprise, Information Technologies and International Development, 3(3), 81-100 http://www.mitpressjournals.org/toc/itid/3/3

Gakuru, M. Winters, K. and Stepman, F. 2009. Inventory of Innovative Farmer Advisory Services Using ICTs, Forum for Agricultural Research in Africa, Feb. http://www.faraafrica.org/media/uploads/File/NSF2/RAILS/Innovative_Farmer_Advisory_Systems.pdf

Hellstrom, J. 2010. The Innovative Use of Mobile Applications in East Africa, SIDA Review 2010:12, Swedish International Development Cooperation Agency, Stockholm http://upgraid.files.wordpress.com/2010/06/sr201012_sida_hellstrom.pdf

Kinkade, S. and Verclas, K. (2008) Wireless Technology for Social Change: Trends in Mobile Use by NGOs, Access to Communication Publication Series, Vodafone Group Foundation and the UN Foundation Partnership, Washington, D.C. http://mobileactive.org/files/MobilisingSocialChange_full.pdf

Martin, B. L. 2010. Mobile phones and rural livelihoods: An exploration of mobile phone diffusion, uses, and perceived impacts of uses among small- to medium-size farm holders in Kamuli District, Uganda" Graduate Theses and Dissertations.Paper 11452. http://lib.dr.iastate.edu/etd/11452

McNamara, K. 2003. Information and communication technologies, poverty and development:Learning from experience. Retrieved on March 10, 2009, from http://www.infodev.org/en/Document.17.PDF 
National Bureau of Statistics (NBS) 2011. Nigeria National Mobile Phone Penetration Ranking: Survey carried out by National Bureau of Statistics in collaboration with the Central Bank of Nigeria (CBN) across all states of Nigeria. Retrieved on September 20, 2012 on www.technologytimes.ng.com.

Onwuemele, A. 2011. Impact of Mobile Phones On Rural Livelihoods Assets in Rural Nigeria: A Case Study Of Ovia North East Local Government Area. JORIND 9(2). Retrieved October 3, 2012 from www.transcampus.org., www.ajol.info/journals/jorind

Rogers, E. 2003. Diffusion of Innovations. New York: Simon \& Schuster, Limited.

Saunders, R., Warford, J., and Wellenius, B. 1994. Telecommunications and economicdevelopment. Baltimore, MD: The Johns Hopkins University Press

Scoones, I. 1998. Sustainable rural livelihoods: A framework for analysis. Retrieved on March 18, 2009, from http://www.ids.ac.uk/ids/bookshop/wp/wp72.pdf.

Verlaeten, M.P. 2002. Policy Frameworks for the Knowledge Based Economy: ICTs, Innovation and Human Resources - An OECD Global Forum, OECD, Paris. http://www.oecd.org/dataoecd/49/11/1961062.pdf

Wade, R.H. 2004. Bridging the Digital Divide: New Route to Development or New Form of Dependency, In: Avgerou, C. Ciborra, C. and Land, F. (eds), The Social Study of Information and Communication Technology Innovation, Actors, and Context. 185-206. New York: Oxford University Press.

Winkelman, R. 2000. Econometric analysis of count data. Heidelberg, Germany: Springer-Verlag

Woodridge, J.M. 2002. Econometric analysis of cross sectional data and panel data. Cambridge and London: MIT press 